\title{
Violence against Women: A Study of Underlying Factors in Tehran Forensic Center 2001
}

\author{
Roya Azizian ${ }^{1}$, Bagher Saroukhani ${ }^{2}$, Mahmod Mahmodi $^{3} \&$ Fereshteh Farzianpour $^{4}$ \\ ${ }^{1}$ School of Public Health and Institute of Public Health Research, Tehran University of Medical Sciences, Tehran, \\ Iran \\ ${ }^{2}$ Department of Sociology University of Tehran, Iran \\ ${ }^{3}$ Department of Epidemiology and Biostatistics, School of Public Health and Institute of Public Health Research, \\ Tehran University of Medical Sciences, Tehran, Iran \\ ${ }^{4}$ Department of Health Management Economics, School of Public Health and Institute of Public Health \\ Research, Tehran University of Medical Sciences, Tehran, Iran \\ Correspondence: Fereshteh Farzianpour, Department of Health Management Economics, School of Public \\ Health and Institute of Public Health Research, Tehran University of Medical Sciences, Tehran, Iran. Tel: \\ 98-21-8898-9128. E-mail: farzianp@sina.tums.ac.ir; r_azizian@hotmail.com
}

Received: January 7, 2016 Accepted: January 28, 2016 Online Published: April 29, 2016

doi:10.5539/gjhs.v8n12p68 URL: http://dx.doi.org/10.5539/gjhs.v8n12p68

\begin{abstract}
Background and Objective: Intimate partner violence (IPV) against women is a global human rights and public health concern. The WHO Multi-Country Study on Women's Health and Domestic Violence documented the widespread nature of IPV with lifetime prevalence of physical and/or sexual parter violence among ever-partnered women in the fifteen sites surveyed ranging from $15 \%$ in Ethiopia province to $71 \%$ in Japan.Across the world, violence against women is a major threat to their physical and mental well-being. This violation of the most fundamental human rights usually takes the form of family or domestic violence.

This study was conducted to determine the violence against women in Tehran in forensic center in 2001.

Methods: Data for this cross-sectional study were collected from women referring to Tehran Forensic Center, with a view to obtaining a realistic picture of violence to women.

Data were gathered on 120 subjects randomly selected women who completed questionnaires and interview.

Results: The women in this study had presented with wounds and injuries inflicted by their husbands. These women had been referred to the Center by family courts to complete legal formalities concerning injury diagnosis and duration of treatment.

The main factors underlying family violence were examined from five different aspects: behavioral and educational problems $(79.2 \%)$, financial strain $(54.2 \%)$, and interference by the husband's family (39.2\%), sexual problems (13.3\%), and differences in culture and social class $(10 \%)$.

Conclusion: Factors found to have an accelerating or interfering role included the woman's age and the couple's education level. However, many women declared that several factors were contributing simultaneously to the problem of violence.
\end{abstract}

Keywords: family violence, women, forensic medicine

\section{Background}

Intimate partner violence (IPV) against women is a global public health and human rights concern. Despite a growing body of research into risk factors for IPV, methodological differences limit the extent to which comparisons can be made between studies (Abramsky et al., 2011). Intimate partner violence (IPV) against women is a global human rights and public health concern. The WHO Multi-Country Study on Women's Health and Domestic Violence documented the widespread nature of IPV (Garcia-Moreno et al., 2006), with lifetime prevalence of physical and/or sexual parter violence among ever-partnered women in the fifteen sites surveyed ranging from $15 \%$ in Ethiopia province to $71 \%$ in Japan. Between $4 \%-54 \%$ of respondents reported Intimate 
partner violence (IPV) against women is a global human rights and public health concern. The WHO Multi-Country Study on Women's Health and Domestic Violence documented the widespread nature of IPV (Garcia-Moreno et al., 2006), with lifetime prevalence of physical and/or sexual partner violence among ever-partnered women in the fifteen sites surveyed ranging from $15 \%$ in Ethiopia province to $71 \%$ in Japan. Between $4 \%-54 \%$ of respondents reported exper iencing this violence in the year prior to the survey. In addition to being a concern in its own right, IPV is associated with a range of adverse physical, mental, sexual and reproductive health outcomes (Mayhew et al., 2002; Cambell et al., 2002; Ellberg et al., 2008; Maman et al., 2000; Garcia-Moreno et al., 2000; Jewkes et al., 2003; Dunkle et al., 2004). Designing effective IPV prevention programmes involves identification of risk factors-both those that are direct causes of IPV, and those that point to common characteristics of victims and/or perpetrators thus allowing appropriate tailoring and targeting of services. Studies in various countries have identified a range of factors that influence IPV risk (Koeing et al., 2006; Naved et al., 2005; Parish et al., 2004; Kishor et al., 2008; Stith et al., 2004), but in some cases, protective factors in one setting may be ineffective or actually increase risk in another (Ellberg et al., 2001). For the purposes of intervention development, there is considerable interest in identifying a set of risk and protective factors for IPV that behave consistently across settings, to maximize chances of intervention success and minimize chances of inadvertently doing harm. It is difficult to make comparisons between settings using existing individual studies as differences in identified risk factors may either be methodological artifacts or a real reflection of contrasting phenomena. Selected Demo-graphic and Health Surveys (Kishor et al., 2008 \& 2004) have added a Domestic Violence Module; however, country-level adaptations to the module and interviewer training procedures still limit their comparability. Standardization is very important in a research field where even individual interviewer effects have a profound effect on level of disclosure (Ellberg et al., 2001). According to global statistics, the rates of death and disability resulting from violence to women of reproductive is comparable to those from cancers and more than those due to car accidents and infectious diseases (Abramsky, 2011).

Violence against women (VAW) is, collectively, violent acts that are primarily or exclusively committed against women. Sometimes considered a hate crime, (Angelari, 1997; Gerstenfeld et al., 2013; McPhail, 2003) this type of violence targets a specific group with the victim's gender as a primary motive. This type of violence is gender-based, meaning that the acts of violence are committed against women expressly because they are women. The UN Declaration on the Elimination of Violence against Women states that:

"Violence against women is a manifestation of historically unequal power relations between men and women" and that "violence against women is one of the crucial social mechanisms by which women are forced into a subordinate position compared with men." ("A/RES/48/104-Declaration on the Elimination of Violence against Women”. United Nations General Assembly, 2014).

Kofi Annan, Secretary-General of the United Nations, declared in a 2006 report posted on the United Nations Development Fund for Women (UNIFEM) website that:

Violence against women and girls is a problem of pandemic proportions. At least one out of every three women around the world has been beaten, coerced into sex, or otherwise abused in her lifetime with the abuser usually someone known to her (Moradian, 2010).

Violence against women can fit into several broad categories. These include violence carried out by "individuals" as well as "states". Some of the forms of violence perpetrated by individuals are rape; domestic violence; sexual harassment; coercive use of contraceptives; female infanticide; prenatal sex selection; obstetric violence and mob violence; as well as harmful customary or traditional practices such as honor killings, dowry violence, and female genital mutilation, marriage by abduction and forced marriage. Some forms of violence are perpetrated or condoned by the state such as war rape; sexual violence and sexual slavery during conflict; forced sterilization; forced abortion; violence by the police and authoritative personnel; stoning and flogging. Many forms of VAW, such as trafficking in women and forced prostitution are often perpetrated by organized criminal networks (Prügl, 2013; Susskind, 2014; Det jag har bevittnat i al-Raqqa kommer alltid förfölja mig”. Nyheter Världen et al., 2014; Ahmed, 2014; Brekke, 2014; Watson, 2014).

The World Health Organization (WHO), in its research on VAW, categorized it as occurring through five stages of the life cycle: "1) pre-birth, 2) infancy, 3) girlhood, 4) adolescence and adulthood and 5) elderly" (World Health Organization, 1993, 1994, 2013). Family is the first and most stable social institution which human's identity and sociability of a person is formed in it and is the reason for acceptance of values and social norms as well as transferring relation patterns and interaction from the family to other social institutions. Without any doubt there is no social damage which can be away from family (Saroukhani, 2000). Thus existence of violence 
in family patterns will have its effect on society and lead to continuation of rough patterns and behaviors in society. Children whom their mothers suffer from physical abuse of fathers are in danger of higher risk factors for transferring rough behaviors to next generations (American Psychological Association, 1996). Most husbands that have harmful behavior toward their wives have witnessed harmful behavior of their father toward their mother (Roy, 1998). Woman abuse transfers over generations and threats not only the present generation but also future generations as well (Nazparvar, 1997). History of violence in parents is more effective in woman abuse issue compared to environmental issues (Kalami, 1999). In Germany more than a thousand children become victim of child abuse over a year that most of them also suffer from violence between parents (Kerdovani, 2000).

Violence behavior toward women can be observed in all societies and countries and in all society and economic levels. Studies show that people who are in lower levels in terms of economy are in danger of higher levels of violence factors.

Economic problems (Saroukhani, 1999) are the most important factor of family violence (American Psychological Association, 1996). Based on worldwide statistics extend of mortality and disability caused by violence among women who are in childbearing age is equal to extend of mortality caused by cancer and is higher than casualties caused by driving accidents and infectious diseases (Heise et al., 1994). In United States of America over a year about one to four million women become victim of violence from their husbands. 40 to 60 percent of men who abuse women are mostly men with low education (American Psychological Association, 1996) and low income or without necessary skills to maintain better and dominant situation may use their violence at home (Brown, 2002). In a study which was concluded on Japanese women who were living in United States of America, cultural factors and institutional values such as tolerance and patience in family relations to maintain reputation, avoiding violence, maintaining and protection family consensus and the most important preventive factor in order to identify violence behavior of their husbands and neutralization has been helping efforts for them.

Based on worldwide report of violence and hygiene (Micko, 2002) which was published in year 2002, violence is an issue that takes effect form several biological, social, cultural, economic and political factors. According to concluded studies, the purpose of this study is reviewing the causes and factors of creating violence in family and this matte that violence issue among Tehran's women is affected by which factors.

\section{Methods}

This study is a cross sectional study carried out in second half of 2001 and in women's Section of forensic center. Study population includes 120 married women abused to violence which were selected using Poisson random sampling and in a two week period from women referring to mentioned section. Data collection was carried out using interviews and questionnaire and questions were designed in a way that interviewees are able to openly provide their answers.

In analysis of data two dimensioned and several dimensioned tables were used and in addition to that for more analysis of data Fisher's Chi-square analysis was used. In this study confidence level was considered to be $95 \%$.

\section{Results}

120 women were selected from women referring to women's section of forensics center during two weeks and in order to review the factors of violence toward them questioning was carried out. Table 1 shows absolute and relative distribution frequency of reviewed units in terms of violence factor and age of women.

Table 1. Absolute and relative frequency distribution of reviewed units in terms of involvement and its status and age of women referring to forensics center of Tehran in 2001

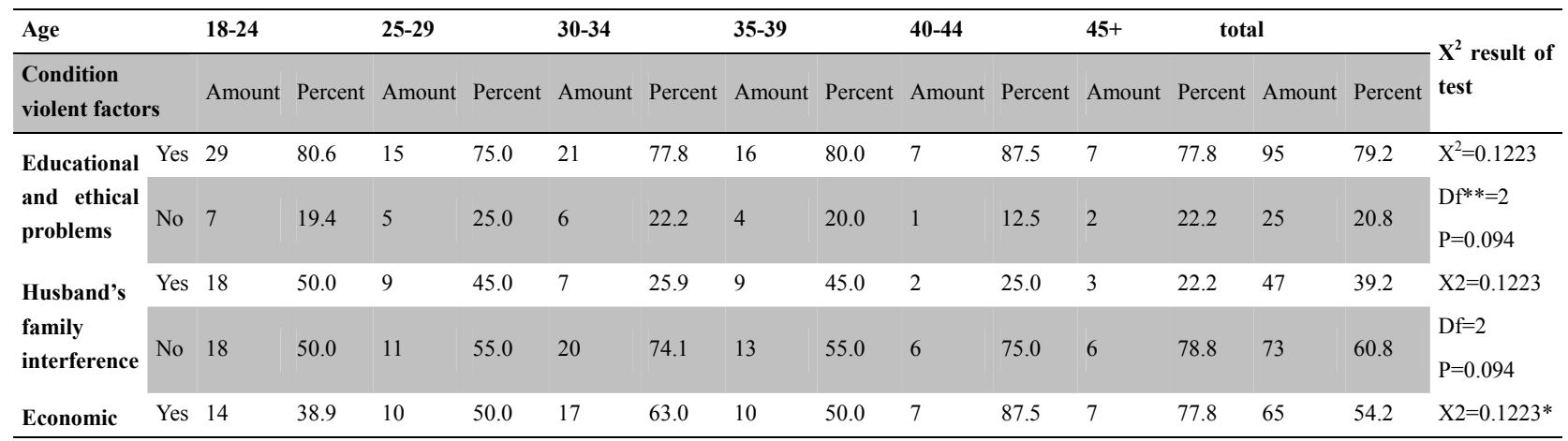




\begin{tabular}{|c|c|c|c|c|c|c|c|c|c|c|c|c|c|c|c|c|}
\hline problems & No & 22 & 61.1 & 10 & 50.0 & 10 & 37.0 & 10 & 50.0 & 1 & 12.5 & 2 & 22.2 & 55 & 45.8 & $\begin{array}{l}\mathrm{Df}=2 \\
\mathrm{P}=0.094\end{array}$ \\
\hline Cultural & Yes & 3 & 8.3 & 3 & 15.0 & 3 & 11.1 & 2 & 10.0 & 1 & 12.5 & 0 & 0 & 12 & 10.0 & $\mathrm{X} 2=0.1223$ \\
\hline $\begin{array}{l}\text { and class } \\
\text { differences }\end{array}$ & No & 33 & 91.7 & 17 & 85.0 & 24 & 88.9 & 18 & 90.0 & 7 & 87.5 & 9 & 100 & 108 & 90.0 & $\begin{array}{l}\mathrm{Df}=2 \\
\mathrm{P}=0.094\end{array}$ \\
\hline Marital & Yes & 7 & 19.4 & 4 & 20.0 & 2 & 7.4 & 2 & 7.4 & 0 & 0 & 1 & 11.1 & 16 & 13.3 & $\mathrm{X} 2=0.1223$ \\
\hline $\begin{array}{l}\text { sexual } \\
\text { problems }\end{array}$ & No & 29 & 80.6 & 16 & 80.0 & 25 & 92.6 & 18 & 92.6 & 8 & 100 & 8 & 88.9 & 104 & 86.7 & $\begin{array}{l}\mathrm{Df}=2 \\
\mathrm{P}=0.094\end{array}$ \\
\hline
\end{tabular}

$\mathrm{P}<0.05$ is in significant level

* indicates that the relation between two variables is statistically significant

** Dfs are formed after merging of rows

Table 2. Absolute and relative frequency distribution of reviewed units in terms of involvement and its status and education of women referring to forensics center of Tehran in 2001

\begin{tabular}{|c|c|c|c|c|c|c|c|c|c|c|c|c|c|c|}
\hline \multirow{2}{*}{\multicolumn{2}{|c|}{$\begin{array}{l}\begin{array}{c}\text { Education of } \\
\text { woman }\end{array} \\
\text { Condition violent } \\
\text { factors amount }\end{array}$}} & \multirow{2}{*}{\multicolumn{2}{|c|}{$\begin{array}{c}\begin{array}{c}\text { Illiterate } \\
\text { education }\end{array} \\
\text { mount percent }\end{array}$}} & \multicolumn{2}{|c|}{$\begin{array}{c}\text { Elementary } \\
\text { education }\end{array}$} & \multicolumn{2}{|c|}{$\begin{array}{c}\text { Middle school } \\
\text { education }\end{array}$} & \multicolumn{2}{|c|}{$\begin{array}{l}\text { High school } \\
\text { education }\end{array}$} & \multicolumn{2}{|c|}{$\begin{array}{c}\text { Higher } \\
\text { education }\end{array}$} & \multicolumn{2}{|c|}{ Total } & \multirow{2}{*}{$\begin{array}{l}X^{2} \text { result of } \\
\text { test }\end{array}$} \\
\hline & & & & amount & percent & amount & percent & amount & percent & amount & percent & amount & percent & \\
\hline \multirow{2}{*}{$\begin{array}{l}\text { Educational } \\
\text { and ethical } \\
\text { problems }\end{array}$} & Yes & 4 & 66.7 & 9 & 90.0 & 26 & 72.2 & 42 & 84.0 & 14 & 77.8 & 95 & 72.2 & $\mathrm{X}^{2}=0.1223$ \\
\hline & No & 2 & 33.3 & 1 & 10.0 & 10 & 27.8 & 8 & 16.0 & 4 & 22.2 & 25 & 20.8 & $\begin{array}{l}\mathrm{Df}=2 \\
\mathrm{P}=0.094\end{array}$ \\
\hline \multirow{2}{*}{$\begin{array}{l}\text { Husband's } \\
\text { family } \\
\text { interference }\end{array}$} & Yes & 2 & 33.3 & 1 & 10.0 & 12 & 33.3 & 23 & 46.0 & 9 & 50.0 & 47 & 39.2 & $\mathrm{X} 2=0.1223$ \\
\hline & No & 4 & 66.7 & 9 & 90.0 & 24 & 66.7 & 27 & 54.0 & 9 & 50.0 & 73 & 60.8 & $\begin{array}{l}\mathrm{Df} * *=2 \\
\mathrm{P}=0.094\end{array}$ \\
\hline \multirow{2}{*}{$\begin{array}{l}\text { Economic } \\
\text { problems }\end{array}$} & Yes & 5 & 83.3 & 6 & 60.0 & 22 & 61.1 & 26 & 52.0 & 6 & 33.3 & 65 & 54.2 & $\mathrm{X} 2=0.1223$ \\
\hline & No & 1 & 16.7 & 4 & 40.0 & 14 & 38.9 & 24 & 48.0 & 12 & 66.7 & 55 & 45.8 & $\begin{array}{l}\mathrm{Df}=2 \\
\mathrm{P}=0.094\end{array}$ \\
\hline \multirow{2}{*}{$\begin{array}{l}\text { Cultural } \\
\text { and class } \\
\text { differences }\end{array}$} & Yes & 0 & 0 & 0 & 0 & 2 & 5.6 & 5 & 10.0 & 5 & 27.8 & 12 & 10.0 & $\mathrm{X} 2=0.1223^{*}$ \\
\hline & No & 6 & 100 & 10 & 100 & 34 & 94.4 & 45 & 90.0 & 13 & 72.2 & 108 & 90.0 & $\begin{array}{l}\mathrm{Df}=2 \\
\mathrm{P}=0.094\end{array}$ \\
\hline \multirow{2}{*}{$\begin{array}{l}\text { Marital } \\
\text { sexual } \\
\text { problems }\end{array}$} & Yes & 0 & 0 & 1 & 10.0 & 4 & 11.1 & 9 & 18.0 & 2 & 11.1 & 16 & 13.3 & $X 2=0.1223$ \\
\hline & No & 4 & 100 & 9 & 90.0 & 32 & 88.9 & 41 & 82.0 & 16 & 88.9 & 104 & 86.7 & $\begin{array}{l}\mathrm{Df}=2 \\
\mathrm{P}=0.094\end{array}$ \\
\hline
\end{tabular}

* indicates that the relation between two variables is statistically significant

** Dfs are formed after merging of rows

Table 3. Absolute and relative frequency distribution of reviewed units in terms of involvement and its status and education of men in women referring to forensics center of Tehran in 2001

\begin{tabular}{|c|c|c|c|c|c|c|c|c|c|c|c|c|c|c|}
\hline \multirow{2}{*}{\multicolumn{2}{|c|}{\begin{tabular}{l}
\multicolumn{1}{c}{$\begin{array}{c}\text { Education of } \\
\text { man }\end{array}$} \\
Condition violent \\
factors amount
\end{tabular}}} & \multirow{2}{*}{\multicolumn{2}{|c|}{$\begin{array}{c}\begin{array}{c}\text { Illiterate } \\
\text { education }\end{array} \\
\text { amount percent }\end{array}$}} & \multirow{2}{*}{\multicolumn{2}{|c|}{$\begin{array}{c}\begin{array}{c}\text { Elementary } \\
\text { education }\end{array} \\
\text { amount percent }\end{array}$}} & \multicolumn{2}{|c|}{$\begin{array}{c}\text { Middle school } \\
\text { education }\end{array}$} & \multicolumn{2}{|c|}{$\begin{array}{l}\text { High school } \\
\text { education }\end{array}$} & \multicolumn{2}{|c|}{$\begin{array}{c}\text { Higher } \\
\text { education }\end{array}$} & \multicolumn{2}{|c|}{ Total } & \multirow{2}{*}{$\begin{array}{l}X^{2} \text { result of } \\
\text { test }\end{array}$} \\
\hline & & & & & & amount & percent & amount & percent & amount & percent & amount & percent & \\
\hline \multirow{2}{*}{$\begin{array}{l}\text { Educational } \\
\text { and ethical } \\
\text { problems }\end{array}$} & Yes & 1 & 33.3 & 14 & 77.8 & 32 & 76.2 & 27 & 84.0 & 21 & 84.0 & 95 & 79.2 & $\begin{array}{l}\mathrm{X}^{2}=0.1223 \\
\mathrm{Df}^{* *}=2\end{array}$ \\
\hline & No & 2 & 66.7 & 4 & 22.2 & 10 & 23.8 & 5 & 16.0 & 4 & 16.0 & 25 & 20.8 & $\mathrm{P}=0.094$ \\
\hline \multirow{2}{*}{$\begin{array}{l}\text { Husband's } \\
\text { family } \\
\text { interference }\end{array}$} & Yes & 1 & 33.3 & 4 & 22.2 & 18 & 42.9 & 12 & 46.0 & 12 & 48.0 & 47 & 39.2 & $\mathrm{X} 2=0.1223$ \\
\hline & No & 2 & 66.7 & 14 & 77.8 & 24 & 57.1 & 20 & 54.0 & 13 & 52.0 & 73 & 60.8 & $\begin{array}{l}\mathrm{Df}=2 \\
\mathrm{P}=0.094\end{array}$ \\
\hline
\end{tabular}




\begin{tabular}{|c|c|c|c|c|c|c|c|c|c|c|c|c|c|c|}
\hline \multirow{2}{*}{$\begin{array}{l}\text { Economic } \\
\text { problems }\end{array}$} & Yes & 3 & 100 & 14 & 77.8 & 26 & 61.9 & 17 & 52.0 & 5 & 20.0 & 65 & 54.2 & $\begin{array}{l}\mathrm{X} 2=0.1223 \\
\mathrm{Df}=2\end{array}$ \\
\hline & No & 0 & 0 & 4 & 22.2 & 16 & 38.1 & 15 & 48.0 & 20 & 80.0 & 55 & 45.8 & $\mathrm{P}=0.094$ \\
\hline \multirow{2}{*}{$\begin{array}{l}\text { Cultural } \\
\text { and class } \\
\text { differences }\end{array}$} & Yes & 0 & 0 & 0 & 0 & 4 & 9.5 & 3 & 10.0 & 5 & 20.0 & 12 & 10.0 & $\begin{array}{l}\mathrm{X} 2=0.1223^{*} \\
\mathrm{Df}=2\end{array}$ \\
\hline & No & 3 & 100 & 18 & 100 & 38 & 90.5 & 29 & 90.0 & 20 & 80.0 & 108 & 90.0 & $\mathrm{P}=0.094$ \\
\hline \multirow{2}{*}{$\begin{array}{l}\text { Marital } \\
\text { sexual } \\
\text { problems }\end{array}$} & Yes & 1 & 33.3 & 1 & 5.6 & 5 & 11.9 & 4 & 18.0 & 5 & 20.0 & 16 & 13.3 & $\begin{array}{l}\mathrm{X} 2=0.1223 \\
\mathrm{Df}=2\end{array}$ \\
\hline & No & 2 & 66.7 & 17 & 94.4 & 37 & 88.1 & 28 & 82.0 & 20 & 80.0 & 104 & 86.7 & $\mathrm{P}=0.094$ \\
\hline
\end{tabular}

From total of 120 studied women in 6 age groups, respectively from 36 cases in group of 18-24, 29 individuals $(80.6 \%)$ declared educational and ethical factor of husband, 18 individuals $(50 \%)$ declared interference of husband's family, 14 individuals (38.9\%) declared economic problems, 3 individuals $(8.3 \%)$ declared cultural difference and class differences and 7 individuals (19.4\%) declared their marital sexual problems as the main factor of violence and abuse.

In age group of 25-29 from total amount of 20 cases, 15 individuals (75\%) declared educational and ethical factor of husband, 9 individuals ( $45 \%)$ declared interference of husband's family, 10 individuals $(50 \%)$ declared economic problems, 3 individuals (15\%) declared cultural difference and class differences and 4 individuals $(20 \%)$ declared their marital sexual problems as the main factor of violence and abuse.

In age group of 30-34 from total among of 27 cases, 21 individuals (77.8\%) declared educational and ethical factor of husband, 7 individuals $(25.9 \%)$ declared interference of husband's family, 17 individuals (63\%) declared economic problems, 3 individuals (11.1\%) declared cultural difference and class differences and 2 individuals (7.4\%) declared their marital sexual problems as the main factor of violence and abuse.

In age group of 35-39 from total among of 20 cases, 16 individuals (80\%) declared educational and ethical factor of husband, 7 individuals $(25.9 \%)$ declared interference of husband's family, 17 individuals $(63 \%)$ declared economic problems, 3 individuals $(11.1 \%)$ declared cultural difference and class differences and 2 individuals (7.4\%) declared their marital sexual problems as the main factor of violence and abuse.

In age group of 40-44 from total among of 8 cases, 7 individuals $(87.5 \%)$ declared educational and ethical factor of husband, 2 individuals $(25 \%)$ declared interference of husband's family, 7 individuals $(87.5 \%)$ declared economic problems, 1 individual (12.5\%) declared cultural difference and class differences and zero percent declared marital sexual problems as the main factor of violence and abuse.

from total among of 20 cases in group age of 45 and above, 7 individuals (77.8\%) declared educational and ethical factor of husband, 3 individuals (22.2\%) declared interference of husband's family, 7 individuals (77.8\%) declared economic problems, zero percent declared cultural difference and class differences and 1 individual (11.1\%) declared their marital sexual problems as the main factor of violence and abuse.

Reviews show that educational and ethical problems in 6 age groups are approximately close to each other meaning that it does not decrease by age increase.

In case of interference of husband's family this factor is more effective in lower ages compared to higher ages which value of table show its decrease in age group of 40-44.

In case of economic problems values of table indicates that from 6 studied age groups, this factor was related to age variable and a significant correlation can be observed. In case of cultural difference and class differences and marital sexual problems no relation between age and mentioned factors could be observed.

Another variable that was reviewed in this study with factors of violence is education of women. In table 2 women were classified in five groups of Illiterate, elementary, middle, high school and higher education.

In group of Illiterate education from total of 6 women, 4 individuals $(66.7 \%)$ declared educational and ethical factor of husband, 2 individuals $(33.3 \%)$ declared interference of husband's family, 5 individuals $(83.3 \%)$ declared economic problems, zero percent declared cultural difference and class differences and zero percent declared their marital sexual problems as the main factor of violence and abuse. In this group most common factors have been announced to be economic problems (83.3\%) and educational and ethical factor $(66.7 \%)$.

In group of elementary education from total of 10 individuals, 9 individuals $(90 \%)$ declared educational and ethical factor of husband, 1 individual (10\%) declared interference of husband's family, 6 individuals $(60 \%)$ 
declared economic problems, zero percent declared cultural difference and class differences and 1 individual $(10 \%)$ percent declared their marital sexual problems as the main factor of violence and abuse. Also in this group most common factors have been announced to respectively be educational and ethical factor $(90 \%)$ and economic problems $(60 \%)$.

In group of middle school education from total of 36 women, 26 individuals (72.2\%) declared educational and ethical factor of husband, 12 individuals $(33.3 \%)$ declared interference of husband's family, 22 individuals (61.1\%) declared economic problems, 2 individuals (5.6\%) declared cultural difference and class differences and 4 individuals (11.1\%) percent declared their marital sexual problems as the main factor of violence and abuse. Also in this group most common factors have been announced to be educational and ethical factor and then economic problems.

In group of high school education from total of 50 women, 26 individuals (84\%) declared educational and ethical factor of husband, 23 individuals (46\%) declared interference of husband's family, 26 individuals (52\%) declared economic problems, 5 individuals $(10 \%)$ declared cultural difference and class differences and 9 individuals $(18 \%)$ percent declared their marital sexual problems as the main factor of violence and abuse. Also in this group most common factors have been announced to be educational and ethical factor $(84 \%)$ and economic problems $(52 \%)$.

In group of higher education from total of 18 individuals, 14 individuals $(77.8 \%)$ declared educational and ethical factor of husband, 9 individuals (50\%) declared interference of husband's family, 6 individuals (33.3\%) declared economic problems, 5 individuals $(28.8 \%)$ declared cultural difference and class differences and 2 individuals (11.1\%) percent declared their marital sexual problems as the main factor of violence and abuse. Also in this group most common factors have been announced to be educational and ethical factor $(77.8 \%)$ and economic problems $(50 \%)$. In this group economic problems do not play an important role. Results of tables indicated that among studied women two groups of Illiterate and elementary have no problem with their husbands in terms of cultural difference and class differences and the more educational women become the higher this problem gets and its higher amount is related to women with higher educations. In terms of statics there is a significant relation between these two factors.

Method of relation between education of men and violent factors in table 3 shows that in group of Illiterate men, from total of 3 men, 1 individual (33.3\%) declared educational and ethical factor of husband, 1 individual (33.3\%) declared interference of husband's family, 3 individuals (100\%) declared economic problems, zero percent declared cultural difference and class differences and 1 individual (33.3\%) declared their marital sexual problems.

In group of men with elementary education, from total of 18 men, 14 individuals (77.8\%) declared educational and ethical factor of husband, 4 individuals (22.2\%) declared interference of husband's family, 14 individuals (77.8\%) declared economic problems, zero percent declared cultural difference and class differences and 1 individual (5.6\%) declared their marital sexual problems.

In group of men with middle education, from total of 42 men, 32 individuals (76.2\%) declared educational and ethical factor of husband, 18 individuals $(42.9 \%)$ declared interference of husband's family, 26 individuals $(61.9 \%)$ declared economic problems, 40 individuals $(95 \%)$ declared cultural difference and class differences and 5 individuals $(11.9 \%)$ declared their marital sexual problems.

In group of men with high school education, from total of 32 men, 27 individuals (84.4\%) declared educational and ethical factor of husband, 12 individuals (37.5\%) declared interference of husband's family, 17 individuals (53.1\%) declared economic problems, 3 individuals (9.4\%) declared cultural difference and class differences and 4 individuals (12.5\%) declared their marital sexual problems as important factors to start violence and abuse.

In group of men with higher education, from total of 25 men, 21 individuals (84\%) declared educational and ethical factor of husband, 12 individuals (48\%) declared interference of husband's family, 5 individuals (20\%) declared economic problems, 5 individuals $(20 \%)$ declared cultural difference and class differences and 5 individuals (20\%) declared their marital sexual problems as background of violence and abuse.

Results of table show that educational and ethical problems exist in all educational groups at same extend in viewpoint of women and by increase in educational level of men their approach in this regard does not change.

In terms of economic problems the relation between this factor and violence of abuse in family is significant meaning that by increased education, economic problems play less important role.

In terms of cultural difference and class differences of man and woman in groups of Illiterate and elementary (zero percent) indicates that there is no difference between man and woman in these two groups and both have 
same cultural and class level.

\section{Discussion}

Violence against women in families is an old and worldwide issue. This type of violence takes place in private environment and usually takes place between individuals that linked together due to kindness, blood or legal relation. In Iran an accurate static of this issue rarely exists. This study tried to review a whether small part of underlying factors of violence in family. Based on findings of this study, woman can be victim of abuse at any ages. In viewpoint of women educational and ethical factor of men in our society induce men that one thing keeping basses of family is dominant and unquestionable power of man at home. Among the most important reviewed factors, educational and ethical factor has the most effect in violence and abuse (79.2\%). Moral and cultural issues are more effective in woman abuse compared to environmental issues (Kalami, 1999). In this study there is a significant relation between age of woman and economic problems. In other words women with higher ages believe economic problems to be effective in violence and abuse more than young woman. Reviews show that work and economic problems create violence and abuse in family (Roy, 1998). Interference of husband's family in marital life decreases by age increase, in a way that women with ages of 4.-44 and 45 and above mentioned this factor to be less in violence compared to younger women, although there is no significant relation in this regard. There is no significant relation between age of women and other effective factors on violence such as marital sexual problems and cultural difference and class differences.

Most men with low education and low income use violence for maintaining their dominant position at home (Brown, 2002).

Reviewing educational status of women in this study show that this matter that violence and abuse are just for families with low educational level and bad economic status is wrong. Education level of women has no effect on intensity of violence (Saroukhani, 1999). By increase in educational level of women differences increase. In other words women with low or no education have no cultural difference and class differences with their husbands. In terms of static values there is a significant relation between education of woman and this factor. There is a significant relation between education of woman and man and occurrence of violence (American Psychological Association, 1996). Women with higher education believe that economic factor causes less violence and its reason can be relative independence which women have because of being at work.

Interference of husband's family in marital life causes more violence in educate women although there is no significant relation between these two. Findings of this study in terms of relation between education level of men and factors of violence at home indicates that increase in education level is not effective on traditional approach of men toward women. In other words as much as men with low education want their wives to be obedient, educated men also believe this matter to be among commonly known axioms of marital life. As it can be observed in table 3 educational and ethical factors in this group of men is also the most important factor of creating violence. There is a significant relation between economic problems factor and education level of man, meaning that by increase of education level of man, this factor will have less role in creating violence.

\section{Contributors}

RA contributed to the conception and design of the work, and the acquisition, analysis and interpretation of data, and drafted the paper. FF, RA, BS, MM and FFcontributed to the conception and design of the work, and the acquisition, analysis and interpretation of data. RA contributed to the conception and design of the work, and the acquisition and interpretation of data. All authors contributed to the revision of the paper and approved the final manuscript for publication. All authors have agreed to be accountable for all aspects of the work in ensuring that questions related to the accuracy or integrity of any part of the work are appropriately investigated and resolved.

\section{Acknowledgments}

We thank sincere cooperation of respected professors Dr. Mohammad Arab, respected deputy of Finance-administrative of forensics center of Tehran, Dr. Alireza Kahani, research vice president of forensics center of Tehran, Mrs. Jafari Director of Women's section of forensics center of Tehran and all of the staff of this organization who helped us in very difficult circumstances.

\section{Funding}

This study was funded by Azad University, Tehran-Iran.

\section{Ethical Approval}

This Research was approved by Vice Chancellor for Research Azad University, Tehran-Iran. And Research and Ethics Committee, 27/01/2000. 


\section{Competing Interests Statement}

The authors declare that there is no conflict of interests regarding the publication of this paper.

\section{References}

A/RES/48/104-Declaration on the Elimination of Violence against Women. United Nations General Assembly.

Abramsky, T., Watts, C. H., Garcia-Moreno, C., Devries, K., Ligia Kiss, Ellsberg, M., ... Heise, L. (2011). What factors are associated with recent intimate partner violence? Findings from the WHO multi-country study on women's health and domestic violence. BMC Public Health, 11, 109. http://dx.doi.org/10.1186/1471 $-2458-11-109$

Ahmed, H. (2014, August 14). The Yezidi Exodus, Girls Raped by ISIS Jump to their Death on Mount Shingal. Rudaw Media Network.

Amber, A., \& Guth, L. P. (2000). Domestic Violence and trauma surgeon. The American Journal of Surgery, 179, 134-139. http://dx.doi.org/10.1016/S0002-9610(00)00245-2

American Psychological Association; Violence and the family: Report of the American Psychological Association Presidential task force on violence and the family. (1996). Annals of Epidemiology, 12(7), 525.

Angelari, M. (1997). Hate Crime Statutes: A Promising Tool for Fighting Violence against Women. In K. J. Maschke (Ed.), Pornography, sex work, and hate speech. Taylor \& Francis.

Brekke, K. (2014, September 8). ISIS Is Attacking Women, And Nobody Is Talking About It. The Huffington Post.

Brown, R. M. (2002). Elsevier. Science. Aggression and Violent Behavior, 7(5), 499-511. http://dx.doi.org/10. 1016/S1359-1789(01)00077-5

Campbell, J., Jones, A. S., Dienemann, J., Kub, J., Schollenberger, J., O’Campo, P., ... Wynne, C. (2002). Intimate partner violence and physical health consequences. Arch Intern Med, 162(10), 1157-1163. http://dx.doi.org/10.1001/archinte.162.10.1157

Declaration on the elimination of violence against women. New York, United Nations. (1994, February 23). (Resolution No. A/RES/48/104). World Health.

Det jag har bevittnat i al-Raqqa kommer alltid förfölja mig. Nyheter Världen (in Swedish) (Dagens Nyheter). (2014, September 23).

Dunkle, K. L., Jewkes, R. K., Brown, H. C., Gray, G. E., McIntryre, J. A., \& Harlow, S. D. (2004). Gender-based violence, relationship power, and risk of HIV infection in women attending antenatal clinics in South Africa. Lancet, 363(9419), 1415-1421. http://dx.doi.org/10.1016/S0140-6736(04)16098-4

Ellsberg, M., Heise, L., Pena, R., Agurto, S., \& Winkvist, A. (2001). Researching domestic violence against women: Methodological and ethical considerations. Stud Fam Plann, 32(1), 1-16. http://dx.doi.org/10. 1111/j.1728-4465.2001.00001.x

Ellsberg, M., Jansen, H. A., Heise, L., Watts, C. H., \& Garcia-Moreno, C. (2008). Intimate partner violence and women's physical and mental health in the WHO multi-country study on women's health and domestic violence: An observational study. Lancet, 371(9619), 1165-1172. http://dx.doi.org/10.1016/S0140-6736 (08)60522-X

Garcia-Moreno, C., \& Watts, C. (2000). Violence against women: its importance for HIV/AIDS. AIDS, 14(Suppl 3), S253-265.

Garcia-Moreno, C., Jansen, H. A., Ellsberg, M., Heise, L., \& Watts, C. H. (2006). Prevalence of intimate partner violence: Findings from the WHO multi-country study on women's health and domestic violence. Lancet, 368(9543), 1260-1269. http://dx.doi.org/10.1016/S0140-6736(06)69523-8

Gerstenfeld, P. B. (2013). Hate Crimes: Causes, Controls, and Controversies. Sage.

Heise, L. L., Pitanguy, J., \& Germain, A. (1994). Violence against women. The hidden health burden, World Bank Discussion papers.

Hindin, M., \& Prügl, E. (2013, November 25). Violence against Women. Gender and International Affairs Class 2013. Lecture conducted from The Graduate Institute of International and Development Studies (IHEID), Geneva, Switzerland.

Jewkes, R. K., Levin, J. B., \& Penn-Kekana, L. A. (2003). Gender inequalities, intimate partner violence and 
HIV preventive practices: Findings of a South African cross-sectional study. Soc Sci Med, 56(1), 125-134. http://dx.doi.org/10.1016/S0277-9536(02)00012-6

Kardovani, A. H. (2000). Reaction of children and youth against home violence and importance of protecting them. Journal of Forensics Center, 68-69.

Kishor, S., \& Ansara, D. (2008). Intimate partner violence among couples in 10 DHS countries: Predictors and health outcomes. DHS Analytical Studies No 18 Calverton, MD: Macro International.

Kishor, S., \& Johnson, K. (2004). Profiling domestic violence: A multicounty study. Calverton, Maryland, USA: ORC Macro.

Koenig, M. A., Ahmed, S., Hossain, M. B., \& Khorshed, A. M. A. B. (2003). Women's status and domestic violence in rural Bangladesh: Individual- and community-level effects. Demography, 40(2), 269-288. http://dx.doi.org/10.1353/dem.2003.0014

Koenig, M. A., Stephenson, R., Ahmed, S., Jejeebhoy, S. J., Campbell, J. (2006). Individual and contextual determinants of domestic violence in North India. American Journal of Public Health, 96(1), 1-7. http://dx.doi.org/10.2105/AJPH.2004.050872

Kolahi, F. (1999). Reviewing the facter affecting woman abuse in one hundred references to forensics center of Tabriz.

Maman, S., Campbell, J., Sweat, M. D., \& Gielen, A. C. (2000). The intersections of HIV and violence: Directions for future research and interventions. Soc Sci Med, 50(4), 459-478. http://dx.doi.org/10.1016/ S0277-9536(99)00270-1

Mayhew, S., \& Watts, C. (2002). Global rhetoric and individual realities: Linking violence against women and reproductive health. In K. Lee, \& S. F. K. Buse (Eds.), Health policy in a globalising world (pp. 159-180). Cambridge: Cambridge University Press.

McPhail, B. (2003). Gender-Bias Hate Crimes: A Review. In B. Perry (Ed.), Hate and bias crime: A reader. Psychology Press.

Moradian, A. (2010, Sptember 10). Domestic Violence against Single and Married Women in Iranian Society. Tolerancy.org. the Chicago School of Professional Psychology.

Naved, R. T., \& Persson, L. A. (2005). Factors associated with spousal physical violence against women in Bangladesh. Studies in Family Planning, 36(4), 289-300. http://dx.doi.org/10.1111/j.1728-4465.2005. 00071.x

Nazparvar, B. (1997). Reviewing physical woman abuse in forensics centers of Tehran.

Parish, W. L., Wang, T., Laumann, E. O., Pan, S., \& Luo, Y. (2004). Intimate partner violence in China: National prevalence, risk factors and associated health problems. International Family Planning Perspectives, 30(4), 174-181. http://dx.doi.org/10.1363/3017404

Roy, M. (1998). Abused women (p. 214). Translated by gharache Daghi, Mehdi, Elmi publishing.

Saroukhani, B. (1999). Violence in Iranian Family. International Conference Violence in Family (2000) World Health Organization 2002, World Report on Violence and Health.

Saroukhani, B. (2000). Family Sociology (pp. 11-12). Soroush Publishing.

Stith, S., Smith, D., Penn, C., Ward, D., \& Tritt, D. (2004). Intimate partner physical abuse perpetration and victimization risk factors: A meta-analytic review. Aggression and Violent Behavior, 10(1), 65-98. http://dx.doi.org/10.1016/j.avb.2003.09.001

Susskind, Y. (2014). Under Isis, Iraqi women again face an old nightmare: Violence and repression. The Guardian.

Violence against women: Definition and scope of the problem. (n. d.). World Health Organization, 1, 1-3.

Watson, I. (2014, October 30). 'Treated like cattle': Yazidi women sold, raped, enslaved by ISIS. CNN.

World Bank. World Development Report. (1993). Investing in health. New York, Oxford University Press.

Yoshinhama, M. (2002). Battered women's coping strategies and Psychological distress: Differences by Immigration status. American Journal of Community Psychology, 30, 429-452. http://dx.doi.org/10.1023/ A: 1015393204820 


\section{Copyrights}

Copyright for this article is retained by the author(s), with first publication rights granted to the journal.

This is an open-access article distributed under the terms and conditions of the Creative Commons Attribution license (http://creativecommons.org/licenses/by/3.0/). 